\title{
Spring distributions and relationships with land cover and hydrogeologic strata in a karst landscape in Winona County, Minnesota, USA
}

\author{
Mary A. Williams • Bruce Vondracek
}

Accepted: 28 October 2010/Published online: 25 November 2010

(C) Springer-Verlag (outside the USA) 2010

\begin{abstract}
Karst aquifers are important groundwater resources, but are vulnerable to contamination due to relatively rapid subsurface transport. Springs, points where the landscape and water table intersect and cold groundwater discharges, link aquifer systems with land surfaces and water bodies. As such, in many regions, they are critical to the viability of lakes, streams and cold-water fish communities. An understanding of where springs are located is important to watershed, fishery and environmental management efforts in karst regions. To better understand spatial distribution of springs and as a potential method for identifying variables that characterize locations of springs for improved land and watershed management, a nearest-neighbor analysis and a discriminant function analysis (DFA) of springs were conducted in Winona County, Minnesota, USA, a karst landscape. Nearestneighbor analysis examined the spatial spring distribution. Twenty-two variables describing the locations of springs were analyzed to ascertain their ability to discriminate correct aquifer unit or bedrock unit classification for each spring. Springs were clumped with the highest densities in
\end{abstract}

Minnesota Cooperative Fish and Wildlife Research Unit is jointly sponsored by the U S Geological Survey, the University of Minnesota, the Minnesota Department of Natural Resources, the US Fish and Wildlife Service, and the Wildlife Management Institute.

M. A. Williams $(\square)$

Department of Soil Water and Climate, University of Minnesota, 439 Borlaug Hall, 1991 Upper Buford Circle,

St. Paul, MN 55108-6028, USA

e-mail: williams@umn.edu

B. Vondracek

U.S. Geological Survey, Minnesota Cooperative Fish and Wildlife Research Unit, 1980 Folwell Ave.,

St. Paul, MN 55108, USA the lowest elevations. Springs were correctly assigned to aquifer units and bedrock units with eight and 11 landscape variables, respectively. Forest land cover was the only land cover type contributing to spring discrimination. Consideration of upland human activities, particularly in forested areas, on spring discharge along with a better understanding of characteristics describing spring locations could lead to better management activities that locate and protect springs and their important contributions to regional ecohydrology.

Keywords Karst $\cdot$ Spring $\cdot$ Ecohydrology ·

Nearest-neighbor analysis (NNA) - Discriminant function analysis (DFA) $\cdot$ Minnesota

\section{Introduction}

The term 'karst' defines predominately limestone and dolostone landforms primarily weathered through a chemical dissolution process. Globally, an estimated $50,000,000 \mathrm{~km}^{2}$ (Gvozdetskii 1967) or 20\% (White 1988) of the earth's land surface is karst. In the United States (US), approximately $25 \%$ of bedrock is karst (Thomas Aley 2002, personal communication). Over geologic time, karst bedrock features such as springs, sinkholes, and caves form on and under the landscape adding an underground dimension to land and watershed management. Because these features focus storm-water or melt-water runoff quickly into the subsurface, little or no filtering of pollutants occur making these systems vulnerable to nonpoint source contamination.

Springs, points where the landscape and water table intersect and groundwater discharges, link regional aquifer systems with land surfaces and water bodies. Springs in 
karst regions have been used to study discharge as a possible indicator of water quality (Mahler and Lynch 1999; Wicks et al. 2004; Davis et al. 2005; Zhou et al. 2008), to study aquifer characteristics (Bonacci 1993; Doerfliger et al. 1999; Amit et al. 2002; Toran et al. 2007), and to examine interactions between spring flow and biological activity (Bartodziej and Perry 1990; Wilcox et al. 2005; Tenorio and Drezner 2006).

In many karst regions, springs are a critical cold-water habitat component for fish hatcheries and aquatic fish species (Anderson 1983; McClendon and Rabeni 1987; Thorn 1988; Blann et al. 2002; Brabrand et al. 2002; Whitledge et al. 2006; Brewer et al. 2007). In the midwestern US, hydrogeologic characteristics have been related to trout stream habitat quality (Poff and Allan 1995; Richards et al. 1996). Characteristics describing geology and regional land use have also been linked to stream water quality, invertebrate production and trout population characteristics (Krueger and Waters 1983; Troelstrup and Perry 1989; Vondracek et al. 2000; Blann et al. 2002).

In many karst regions, cold-water streams arise from or are supplemented by cold groundwater springs critical for creating and maintaining viable trout habitat. Trout fishing contributes to the local economy through impacts on tourist operations, local business transactions, fish hatchery operations, park visitations and local food markets. Natural resource managers have long understood the need to conserve cold-water inputs to trout streams and research continues to inform the need for a better understanding of the fundamental relationships between land-use management and cold-water ecosystems. Consideration of human activities upland of spring discharge is important for informing management activities that could protect springs and their important contributions to the ecohydrology of the region.

Tools useful for identifying characteristics that could be used to identify likely locations of springs could inform land planning activities (e.g., zoning), natural resource protection and water management. The goal of this study was to examine a multitude of land cover and landform characteristics that could potentially be useful for identifying where springs are located in an environmentally sensitive karst region. Springs in this region are known to be intricately connected with groundwater resources. They are a critical cold-water habitat component of trout streams and support regional fishing activities that have recently been valued as a multi-million dollar economic industry for the human communities living in this area (Gartner et al. 2002; Hart 2008). In this karst region of southeastern Minnesota, springs were examined from Winona County, a county similar in geology to the regional karst area and one of the few counties in the region with a geographic information database containing spatially explicit geologic and karst information.
Study objectives were to (1) conduct a nearest-neighbor analysis to examine the distribution of springs across the county and then to (2) use a discriminant function analysis to examine the potential for using characteristics that describe landscape and landform spring locations for discriminating springs into spatially explicit land cover categories or surficial bedrock unit locations. Hypotheses were that springs are located randomly across the landscape and that there are no characteristics that would be useful for identifying likely spatial locations of springs.

If characteristics were found to be important for describing spring locations, these characteristics could be used to improve understanding of spring systems, to improve the potential for locating springs not currently mapped, and for informing land planning activities including land and water management in this and potentially other karst regions.

\section{Methods}

Study site

The southeastern corner of Minnesota, unlike most of Minnesota, escaped most coverage from the most recent North American glaciation, and with almost no glacial drift, is referred to as the Driftless Area Ecoregion (Omernik and Gallant 1988). Numerous karst features such as springs, sinkholes and caves have formed in this area. The study area, Winona County, is located in this Driftless Area (Fig. 1). The topography in this county consists of a Paleozoic plateau dissected by deep valleys with stream tributaries that intersect and discharge into the Mississippi River (Trimble 1993). Between these tributaries lie areas that stand as level plateaus, composed primarily of karst and sandstone. There are 300 springs documented in a georeferenced spatial database for Winona County (Gao et al. 2002).

The eastern boundary of Winona County is the Mississippi River, which establishes the base elevation for the topography of the county. The entrenchment and lowering of the upper Mississippi River during the Pleistocene lowered the regional base level, resulting in upland plateaus subject to greater erosion and dissolution through fluvial processes. The development of Ordovician carbonates in the county is partially controlled by this base-level topography defined by the deep valleys cut into the Cambrian sandstones. These carbonates have been shaped over time from both karst and fluvial processes. With intermittent and perennial streams flowing across the landscape, both surface water and groundwater act as geomorphic agents in the evolution of the landscape. Sinkholes, joints, conduits, and fractures continually evolve as water courses 
Fig. 1 Spring locations and trout streams in Winona County located in the karst region in southeast Minnesota. Approximately $20 \%$ of global land area is karst with an estimated $25 \%$ of land area in the continental United States designated as karst (inset map USGS 2003). In southeast Minnesota, more than 10,000 karst features have been identified and georeferenced for inclusion into a geographic information database created and maintained by the Minnesota Geological Survey (Gao et al. 2002)
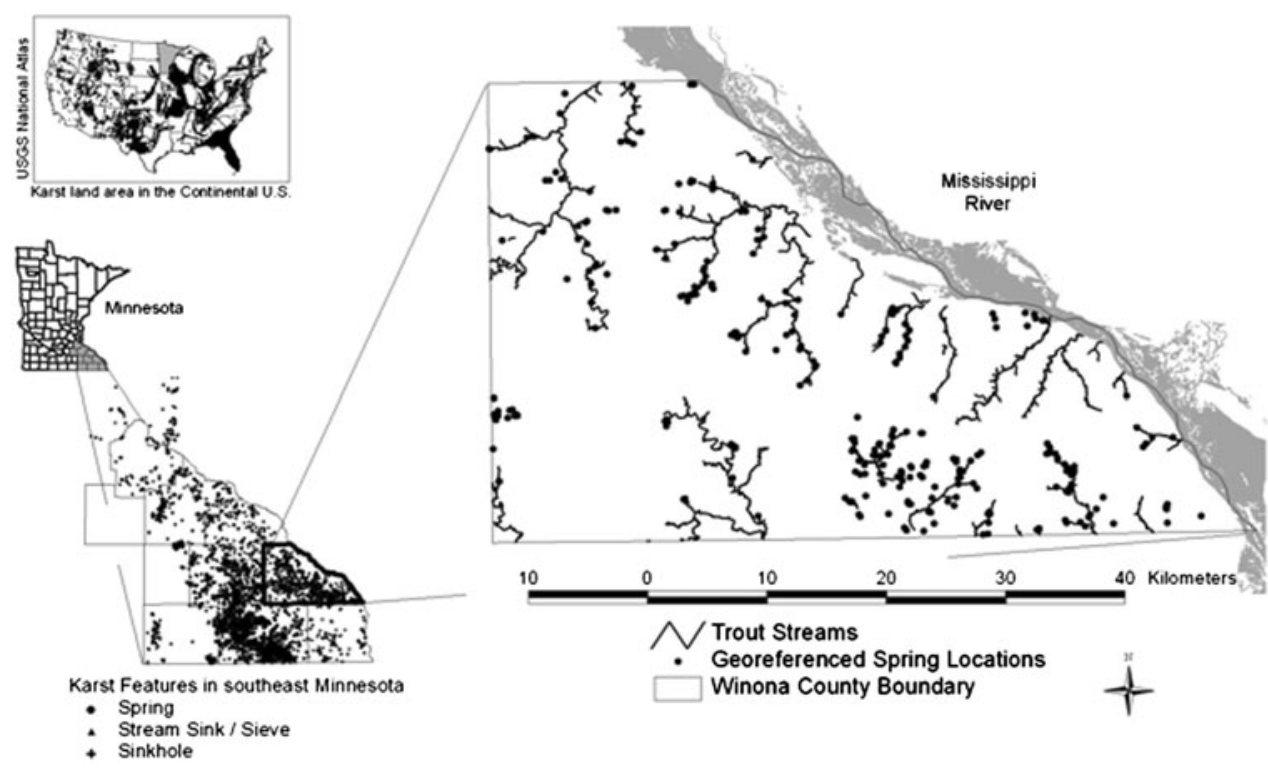

bedrock unit, aquifer unit, geomorphology, general soil classification, and land use/land cover (Table 1).

Two variables were created as indicators of the physical connection between springs and cold-water streams. One variable was created to define the distance from the spring to the nearest stream segment (Dist_to_Stream) and another variable was created to indicate whether or not the nearest stream segment was a designated trout stream (Trout_flag). Distance from spring to nearest stream segment was determined using a Minnesota Department of Natural Resources (MNDNR) Arcview extension (Minnesota Department of Natural Resources 2008a). Stream type (Strm_type) and the stream's trout designation (Trout_flag) were determined from the nearest line segment in the stream line layer. Distance from spring to the nearest bedrock contact (Dist_to_Bedrk) was also determined using the MNDNR extension with the spring point layer and the bedrock geology layer.

Elevation and slope were derived from a United States Geological Survey (USGS) 1:24,000 scale Level 2, 30-m digital elevation model (DEM) for the state of Minnesota. Land cover data were from the 1990 International Land Use/Land Cover data with an original 19 category classification scheme reclassified into 8 land cover categories: urban/rural development (UR), cultivated land (CL), hay/ pasture/grassland (HP), brushland (BL), forest (FR), water (WT), bog/marsh/fen (BM) and mining (MG). Geomorphological designations were derived from a Minnesota Geological Survey (MGS) 1:100,000 geomorphology data layer created for the state of Minnesota. Intersection of the spring and geomorphology layers produced a geomorphology code for each spring combining: a one-character geomorphic association (e.g., "F" = Fluvial), a two-character glacial phase designation (e.g., "Wi" = Wisconsonian), a 
Fig. 2 Generalized stratigraphic column indicating delineations of bedrock units and associated aquifer units for Winona County, Minnesota (adapted from Mossler and Book 1984). The column containing the number of springs is based on currently known spring locations for this county in the regional karst feature database (Gao et al. 2002). As springs are located and georeferenced, they are added to the regional karst database

\begin{tabular}{|c|c|c|c|c|c|c|}
\hline हैं & 气ू̆ & BEDROCK UNTT & 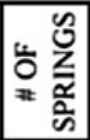 & DESCRIPTION & $\begin{array}{l}\text { AQUIFER } \\
\text { GROUP }\end{array}$ & 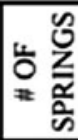 \\
\hline \multirow{3}{*}{\multicolumn{2}{|c|}{ 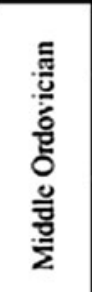 }} & Galena & \multirow[b]{2}{*}{14} & $\begin{array}{l}\text { Fine-grained fossiliferous limestone. Many shale partings in bas } \\
\qquad 15-20 \mathrm{fost} \text {. }\end{array}$ & \multirow{2}{*}{$\begin{array}{l}\text { Galkna. } \\
\text { Upper } \\
\text { Carbonate } \\
\text { Aquifer }\end{array}$} & \multirow[b]{2}{*}{14} \\
\hline & & \begin{tabular}{|c|} 
Dworah Shale. \\
Plateville, Glenwood \\
FMI
\end{tabular} & & $\begin{array}{l}\text { Shale and thin interbeds of limestone. Commonly fossiliferous } \\
\text { Fine-grained fossilierous limestone. Sandy shale. }\end{array}$ & & \\
\hline & & St Peter Sundstone & $\mathbf{0}$ & $\begin{array}{l}\text { Fine- to modium-grained. poorly cemented. quartrose sandstone } \\
\text { busal conkat minot erosional surfase. I'pper surface commonly } \\
\text { iron crusted. }\end{array}$ & $\begin{array}{l}\text { St. Peter } \\
\text { Aquifer }\end{array}$ & \\
\hline \multirow{2}{*}{ 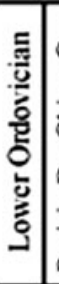 } & \multirow{2}{*}{ 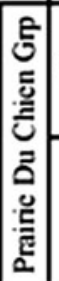 } & Shakopec Formation & & $\begin{array}{l}\text { Thin-bedded and medium-bedded dolomite with thin sandstone } \\
\text { and shale bedk. Bsal } 20 \text { to } 30 \text { feet is fine-grained quartzose } \\
\text { sandstons. }\end{array}$ & \multirow{3}{*}{$\begin{array}{c}\text { Prairic Du } \\
\text { Chicn-Jordan } \\
\text { Aquifer }\end{array}$} & \multirow{3}{*}{72} \\
\hline & & Oncota Dobomite & & $\begin{array}{l}\text { Thick-bedded to massive dolomine. Some sandy dolomite in tase } \\
\qquad 10 \text { to } 20 \text { feet. }\end{array}$ & & \\
\hline \multirow{6}{*}{ 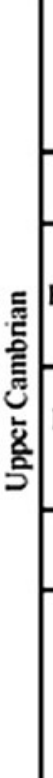 } & & ordan Sandstone & 44 & $\begin{array}{l}\text { Sandstone. Top } 30 \text { foet is thin bodded and well osmented by } \\
\text { calcine. Middle part is medium- to coans-grained quartzose } \\
\text { sandstone: generally uncemented and iron-stained in outcrop. } \\
\text { Basal } 35-40 \text { fest is very fine to finc-grained sandstons. }\end{array}$ & & \\
\hline & & t. Lawrence FM & & Thin-bedded dolomitic siltstone. & \multirow{3}{*}{$\begin{array}{c}\text { St. Lawrence- } \\
\text { Franconia- } \\
\text { Ironton- } \\
\text { Galessille } \\
\text { Aquifer }\end{array}$} & \multirow{3}{*}{214} \\
\hline & Fran & nconia Formation & 176 & $\begin{array}{l}\text { Thin-bedded, dolomite-cemenaed glauconitic sandetoox. Very fiu } \\
\text { to fine grained. }\end{array}$ & & \\
\hline & \multicolumn{2}{|c|}{\begin{tabular}{|c|} 
Ironton \& Galesville \\
Sandstones
\end{tabular}} & 38 & $\begin{array}{l}\text { Ironton: Poorly sorted, silty. fins- to medium-grained quartoose } \\
\text { sandstone with minor glauconite. Galesville: Fine- to medium } \\
\text { grained, well-sorted quartzose sandstone. }\end{array}$ & & \\
\hline & & $\begin{array}{l}\text { Eau Clairc } \\
\text { Formation }\end{array}$ & 0 & $\begin{array}{c}\text { Very fine to fine-grainsd sandstone and siltstone. Inerbedded } \\
\text { shale. }\end{array}$ & $\begin{array}{c}\text { Confining } \\
\text { Layer }\end{array}$ & \\
\hline & & $\begin{array}{l}\text { Mt. Simon } \\
\text { Sandstone }\end{array}$ & 0 & $\begin{array}{l}\text { Fine-to very coarse-grained, poorly cemented sandstone. } \\
\text { Contains pepples in basal } 20 \text { to } 40 \text { feet. Sandstone generally } \\
\text { moderately to well sorted. }\end{array}$ & $\begin{array}{l}\text { Mit. Simon } \\
\text { Aquifer }\end{array}$ & \\
\hline \multicolumn{3}{|r|}{ Precambrian } & & Biotitic granite gneiss in eastem part. Poorly known in west. & Unknown & \\
\hline
\end{tabular}

single digit ordinal value expressing general terrain topography (e.g., "1" = Level) and a one-character designation for the sedimentary association (e.g., "A" = Alluvium).

Soil classification systems provide standard delineations of land areas and, as such, are useful for characterizing general locations of land features. For this study, the soil unit designation for each spring location was derived by intersecting the spring data layer with a general soils classification map of Minnesota. The soil units in this generalized map were delineated based on the parent material, climate, topography, organisms and time (Cummins and Grigal 1980).

Winona County has seven surficial bedrock units (Fig. 3) comprising five aquifer units (Fig. 4). Springs are currently documented in five of these bedrock units and in three of the aquifer units. As a comparison, the potential for discrimination using variables that described spring locations was analyzed separately for bedrock units and then aquifer units. The Shakopee and Oneota bedrock units contained a low number of springs and were merged and treated as one bedrock unit for the bedrock unit discrimination. This pairing is considered to behave as a single hydrologic unit (Kanivetsky 1984).

\section{Statistical analyses}

A nearest-neighbor analysis of the 300 springs in Winona County was conducted using the ArcView 3.2 Nearest 
Fig. 3 Spatial distributions of the seven bedrock units across Winona County, Minnesota. Addition of the spring points would cloud the spatial expression of the bedrock units and are therefore removed from this graphic

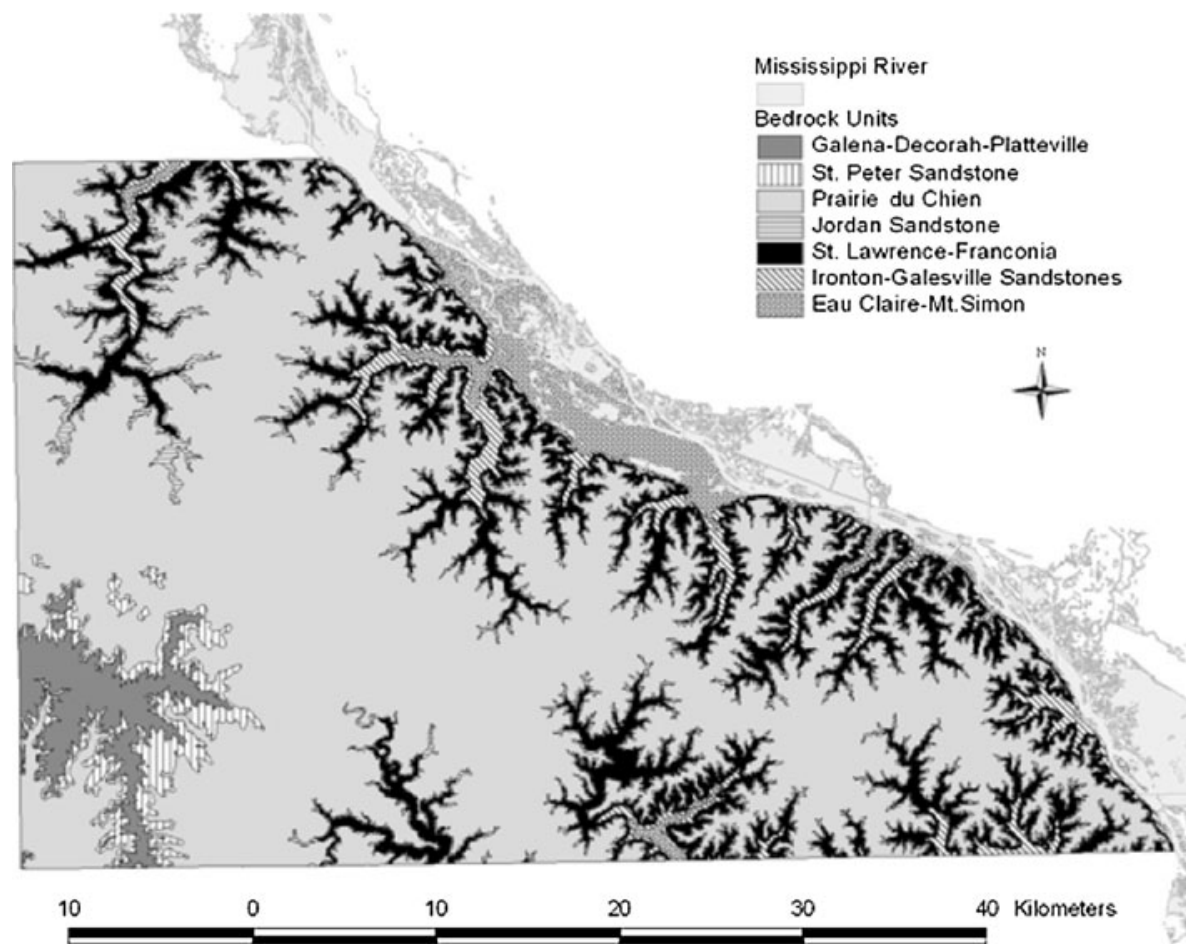

Neighbor Analyst v1.0 extension to test the null hypothesis that springs are located randomly across the landscape.

A Kruskal-Wallis test was used to test the hypothesis that there were no differences in elevation, nearest bedrock contact, nearest stream segment and slope (Table 2) among the bedrock units or among the aquifer units. When differences were found, a Duncan's multiple-range test was used to identify significant differences between units. Categorical characteristics were dummy-coded into separate variables for statistical analyses.

Georeferenced spring points along with the variables describing spring locations were used to conduct discriminate function analyses (DFA) to determine whether subsets of characteristics could be used to classify springs into geologic groups. The general steps in a DFA are to (1) identify the subset of variables most useful for discriminating between groups, (2) create and then evaluate a classification model using the identified subset of variables and (3) test or validate the classification model using a second independent data set.

A stepwise discriminant analysis (SAS v9.1) was conducted to identify which subset of variables discriminated best among the geologic groups to test the null hypothesis that no variables discriminate springs into geologic groups. A random drawing of 200 springs (two-thirds of observations) was used to create and then evaluate a classification model. Remaining observations ( $n=100$, 33\% of observations) were used to validate discriminate functions, producing a predictive classification matrix with error count estimates.

\section{Results}

Nearest-neighbor analysis $(R=0.45, t=18.21)$ indicated that the springs in Winona County are clumped. Mean spring elevation was $277 \mathrm{~m}$ above sea level with a $25 \%$ slope, and located $60 \mathrm{~m}$ from the nearest stream segment and $90 \mathrm{~m}$ from the nearest bedrock contact. The greatest number and density of springs and the longest length of trout streams were in the St. Lawrence-Franconia Formation bedrock unit and the St. Lawrence-Franconia-Ironton-Galesville aquifer unit (Table 3). Among the bedrock units, the Prairie du Chien bedrock unit had the largest area of land and the lowest spring density. Among the aquifer units, the Prairie du Chien-Jordan aquifer unit had the largest area of land and the lowest spring density. The Galena aquifer unit and Galena bedrock unit each represent the same spatial area. This area, the stratigraphically highest and spatially smallest unit, had the smallest length of total stream length and did not contain any trout stream segments. 
Table 1 Landscape and landform variables describing the location of a spring. The value of each variable is derived for each spring by intersecting a spatial data of spring points with spatial layers containing these variables in a geographic information system

\begin{tabular}{|c|c|c|}
\hline Variable & Type $^{\mathrm{a}}$ & Description \\
\hline \multirow[t]{4}{*}{ Aquifer unit } & & Geologic aquifer system at spring location (see Fig. 4) \\
\hline & $\mathrm{D}$ & Galena-Upper Carbonate aquifer unit \\
\hline & $\mathrm{D}$ & Prairie du Chien-Jordan aquifer unit \\
\hline & $\mathrm{D}$ & St. Lawrence-Franconia-Ironton Galesville aquifer unit \\
\hline Dist_to_Bedrk & $\mathrm{N}$ & Distance from spring to closest bedrock boundary \\
\hline Elevation & $\mathrm{N}$ & Elevation of spring in meters above sea level \\
\hline Slope & $\mathrm{N}$ & Slope of the land where spring is located \\
\hline Dist_to_Stream & $\mathrm{N}$ & Distance from spring to nearest stream segment \\
\hline \multirow[t]{6}{*}{ Bedrock unit } & & Geologic bedrock unit at spring location (see Fig. 3) \\
\hline & $\mathrm{D}$ & Galena Formation \\
\hline & $\mathrm{D}$ & Prairie du Chien \\
\hline & $\mathrm{D}$ & Jordan Sandstone \\
\hline & $\mathrm{D}$ & St. Lawrence-Franconia Formation \\
\hline & $\mathrm{D}$ & Ironton Galesville Sandstones \\
\hline Geomorphology & & Landform code \\
\hline FHo1A & $\mathrm{D}$ & Fluvial, Holocene, level topography, alluvium sedimentary association \\
\hline Fwi1Rng & $\mathrm{D}$ & Fluvial, Wisconsonian, level topography, terrace, non-glacial source \\
\hline TWp2B & $\mathrm{D}$ & $\begin{array}{l}\text { Dissected bedrock terrane, Pre-Wisconsonian, rolling to undulating topography, bedrock } \\
\text { dominated }\end{array}$ \\
\hline TWp4Blo & $\mathrm{D}$ & $\begin{array}{l}\text { Dissected bedrock terrane, Pre-Wisconsonian, steep, bedrock dominated, loess mantled } \\
\text { sediment }\end{array}$ \\
\hline TWp5Blo & $\mathrm{D}$ & $\begin{array}{l}\text { Dissected bedrock terrane, Pre-Wisconsonian, inclined slopes intermediate between } \\
\text { rolling and steep, bedrock dominated, loess mantled sediment }\end{array}$ \\
\hline Soils & & Minnesota soil unit associations \\
\hline 419 & $\mathrm{D}$ & Udorthent, fine-loamy \\
\hline 902 & $\mathrm{D}$ & Hapludoll, fine-loamy/sandy \\
\hline 903 & $\mathrm{D}$ & Hapludalf, fine-silty \\
\hline 905 & $\mathrm{D}$ & Paleudalf, fine-silty \\
\hline 908 & $\mathrm{D}$ & Hapludalf, fine-loamy \\
\hline 912 & $\mathrm{D}$ & Hapludoll, coarse-loamy \\
\hline \multicolumn{3}{|l|}{$L U L C$} \\
\hline $\mathrm{CL}$ & $\mathrm{D}$ & Cultivated land \\
\hline FR & $\mathrm{D}$ & Forest \\
\hline HP & $\mathrm{D}$ & Hay/pasture/grassland \\
\hline UR & $\mathrm{D}$ & Urban \\
\hline \multicolumn{3}{|l|}{ Strm_type } \\
\hline $\mathrm{S} 20$ & $\mathrm{D}$ & Perennial \\
\hline $\mathrm{S} 21$ & $\mathrm{D}$ & Intermittent \\
\hline Trout_flag & $\mathrm{D}$ & $0=$ not viable trout stream segment, $1=$ otherwise \\
\hline
\end{tabular}

${ }^{a}$ Variable type indicates dummy (D) or numeric $(\mathrm{N})$ variable

Aquifer units

The St. Lawrence-Franconia-Ironton-Galesville aquifer unit had the highest density $\left(0.78\right.$ springs $\left./ \mathrm{km}^{2}\right)$ and the Prairie du Chien-Jordan had the lowest $\left(0.06\right.$ springs $\left./ \mathrm{km}^{2}\right)$ density of springs among the aquifer units (Table 2).
Significant differences were found between aquifer units for elevation (Kruskal-Wallis test, $H=85.6,4 d f$, $p<0.001$ ), distance to nearest bedrock contact (KruskalWallis test, $H=28.2,4 d f, p<0.001)$ and distance to nearest stream segment (Kruskal-Wallis test, $H=12.8,4$ $d f, p<0.002)$. For each of these variables, Duncan's 
Fig. 4 Spatial distribution of the five aquifer units located in Winona County, Minnesota

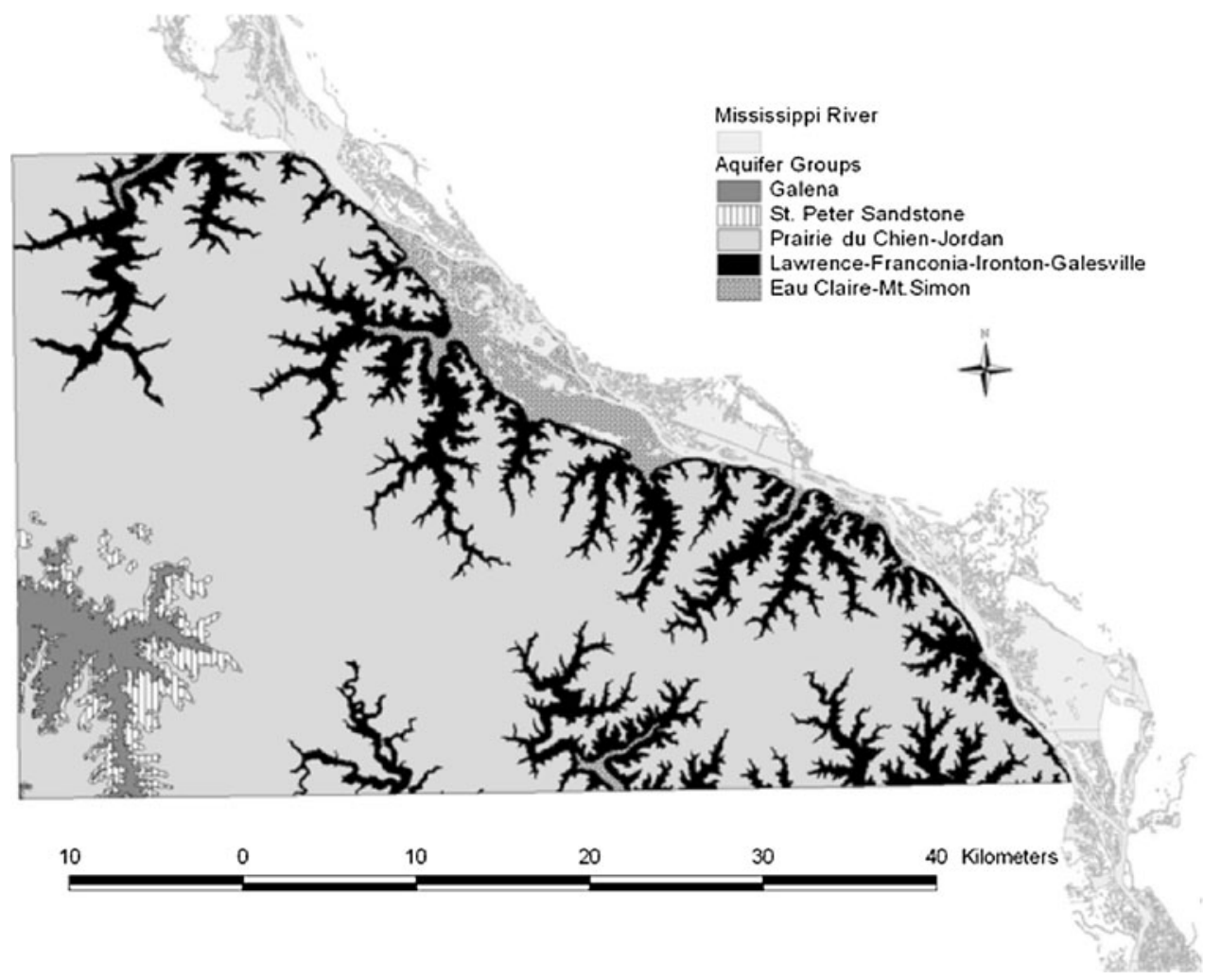

multiple-range tests identified differences between the bedrock units (Table 2). Spring elevation was different (Duncan's multiple-range test $p<0.001$ ) across aquifer units with the Galena Aquifer the highest, the St. Lawrence-Franconia-Ironton-Galesville Aquifer the lowest, and the Prairie du Chien-Jordan Aquifer intermediate. The mean distance to nearest bedrock was similar for the springs in the Galena Formation and springs in the lower elevation Prairie du Chien-Jordan aquifer group, but were greater than for the St. Lawrence-Franconia-IrontonGalesville Aquifer. The Galena Formation had the greatest distance to nearest stream segment (Duncan's multiplerange test $p<0.05$ ) relative to the other two aquifer units. Spring slope was not different among aquifer groups.

Variables that best discriminated spring membership relative to aquifer units were two geomorphology types: TWp2B and Fwi1Rng, three soil types, elevation, forest land cover type, and distance to nearest bedrock contact (Table 3). Geomorphology variable TWp2B reflected contributions of Wisconsonian fluvial and dissected bedrock terrain characteristics to spring classification. Geomorphology variable FWi1Rng, describing fluvial, level topography characterized lower elevations of springs in older bedrock (Fig. 5). Soil units 902, 903, and 908 discriminated springs in the aquifer units. Soil unit 902, representing Hapludoll-dominant soil groups on unglaciated or lightly glaciated slopes, terraces and floodplains (Cummins and Grigal 1980), closely followed the spatial pattern of the
Franconia-Ironton Galesville aquifer unit (Fig. 6) encompassing most springs in the study area. Soil units 903 and 908 were found in the southwestern area of the county. Soil unit 903 described Hapludalf, Haplaquoll, or Hapludolldominant soil groups on eroded till plain and bedrock. Soil unit 908 described Hapludalfs, Arigdolls, or Hapludalfs on unglaciated or lightly glaciated uplands. All of the springs in the Galena bedrock unit and aquifer unit were located on one of these two soil units. On average, the springs in these soil units were at higher elevations, greater distances to the nearest bedrock contact and stream segment, and had lower slopes (Table 4).

The discriminant function analysis discriminated spring membership between aquifer units (Wilks' Lambda = $\left.0.13, F_{16,380}=41.01, p<0.001\right)$. Using the subset of significant variables to create and calibrate a predictive classification matrix of springs classified into aquifer units using a random sample of 200 of the observations, $84 \%$ of the 200 observations were correctly classified. Correct classifications were obtained for $86 \%$ of the springs in the Galena aquifer unit, $84 \%$ in the Prairie du Chien-Jordan and $83 \%$ in the Franconia-Ironton Galesville (Table 5). Validating the predictive capabilities of the classification with the remaining 100 observations, $72 \%$ of the 100 observations were correctly classified. Correct classifications were obtained for $57 \%$ of the springs in the Galena aquifer unit, $86 \%$ in the Prairie du Chien-Jordan and $68 \%$ in the Franconia-Ironton Galesville (Table 6). 


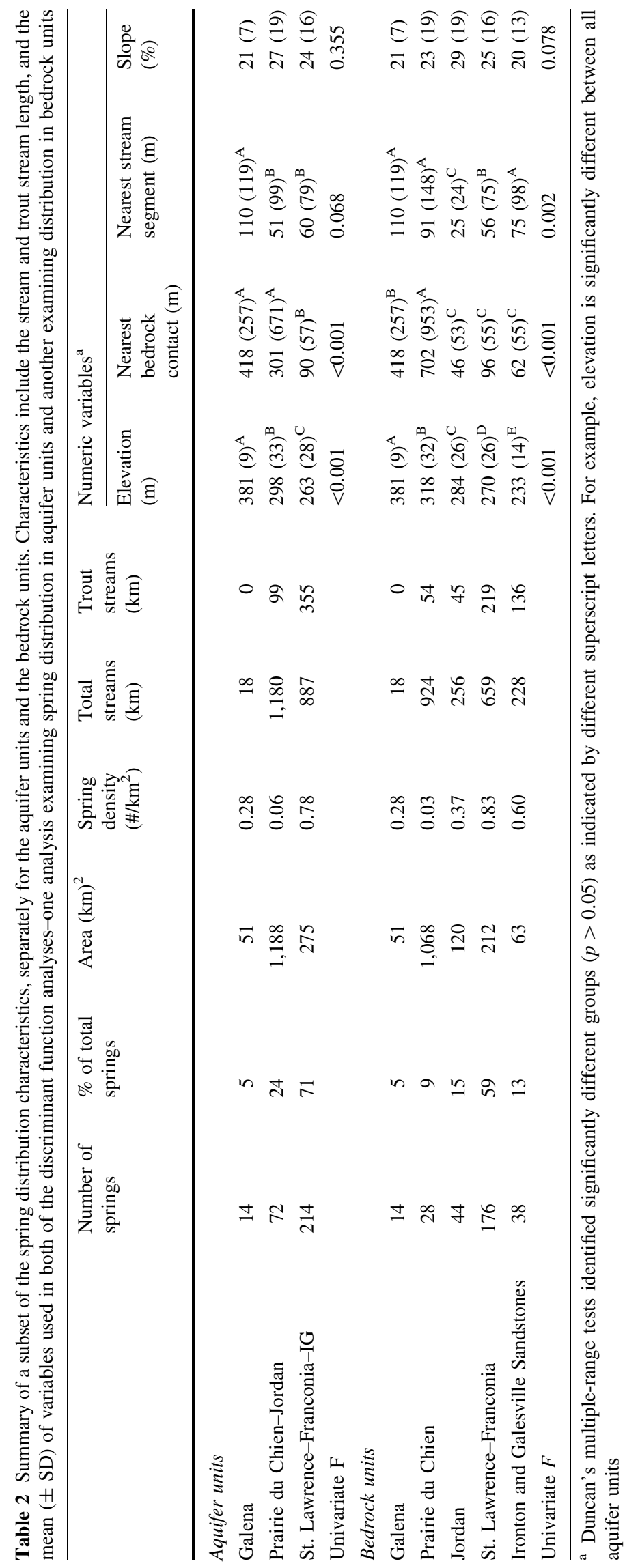


Table 3 Statistical values for variables related to the aquifer and bedrock units based on a discriminate stepwise analysis

\begin{tabular}{lllccll}
\hline Step & Variable(s) & Partial $R^{2}$ & $F$ value & $\operatorname{Pr}>F$ & Wilks' lambda & $\begin{array}{l}\text { Average squared } \\
\text { canonical correlation }\end{array}$ \\
\hline \multicolumn{2}{l}{ Aquifer } & units & & & & \\
1 & S903 & 0.51 & 100.85 & $<0.001$ & 0.49 & 0.25 \\
2 & Elevation & 0.32 & 46.10 & $<0.001$ & 0.34 & 0.36 \\
3 & S908 & 0.14 & 16.27 & $<0.001$ & 0.29 & 0.39 \\
4 & geoTWp2B 0 & 0.39 & 63.24 & $<0.001$ & 0.17 & 0.48 \\
5 & FR & 0.12 & 13.52 & $<0.001$ & 0.15 & 0.53 \\
6 & geoFWi1Rng & 0.06 & 5.77 & 0.00 & 0.14 & 0.55 \\
7 & Dist_Bdrk & 0.03 & 3.05 & 0.05 & 0.14 & 0.55 \\
8 & S902 & 0.04 & 3.73 & 0.03 & 0.13 & 0.56 \\
Bedrock & units & & & & & 0.15 \\
1 & Elevation & 0.59 & 69.66 & $<0.001$ & 0.41 & 0.22 \\
2 & S903 & 0.42 & 34.87 & $<0.001$ & 0.24 & 0.27 \\
3 & S908 & 0.30 & 20.62 & $<0.001$ & 0.17 & 0.32 \\
4 & geoTWp2B & 0.40 & 31.35 & $<0.001$ & 0.10 & 0.35 \\
5 & FR & 0.13 & 6.98 & $<0.001$ & 0.09 & 0.37 \\
6 & S419 & 0.13 & 7.19 & $<0.001$ & 0.08 & 0.39 \\
7 & S912 & 0.11 & 5.84 & 0.00 & 0.07 & 0.41 \\
8 & Dist_Bdrk & 0.08 & 4.22 & 0.00 & 0.06 & 0.42 \\
9 & geoFWi1Rng & 0.06 & 3.07 & 0.02 & 0.06 & \\
10 & trout_flag & 0.05 & 2.64 & 0.04 & 0.06 & 0.43 \\
11 & Strm21 & 0.06 & 2.81 & 0.03 & 0.05 & \\
\hline & & & & & \\
\hline
\end{tabular}

Fig. 5 Relationship of spring locations and distribution of geomorphology variable FWi1Rng describing fluvial, level topography. This landform is found at lower elevations in the county where many springs were also located

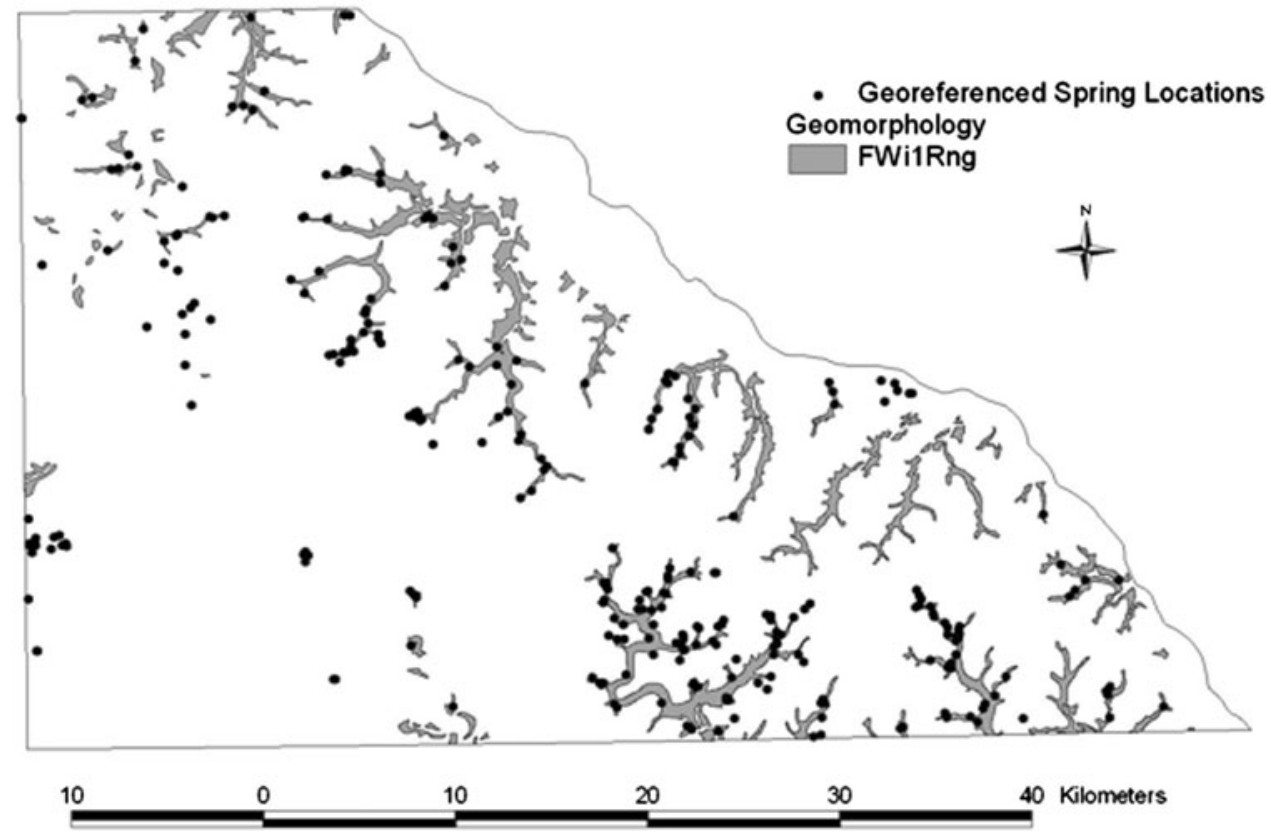

Significant differences were found between bedrock units for elevation (Kruskal-Wallis test, $H=135.2,4$ $d f, \quad p<0.001)$, distance to nearest bedrock contact (Kruskal-Wallis test, $H=63.1,4 d f, p<0.001$ ) and distance to nearest stream segment (Kruskal-Wallis test, $H=15.4,4 d f, p<0.001)$. For each of these variables, 
Fig. 6 Distribution of the St. Lawrence-Franconia-Ironton Galesville aquifer unit and soil unit association 902 describing Hapludoll-dominant soil groups on unglaciated or lightly glaciated slopes, terraces and floodplains (Cummins and Grigal 1980). One-third of all currently identified springs are defined by this soil unit association

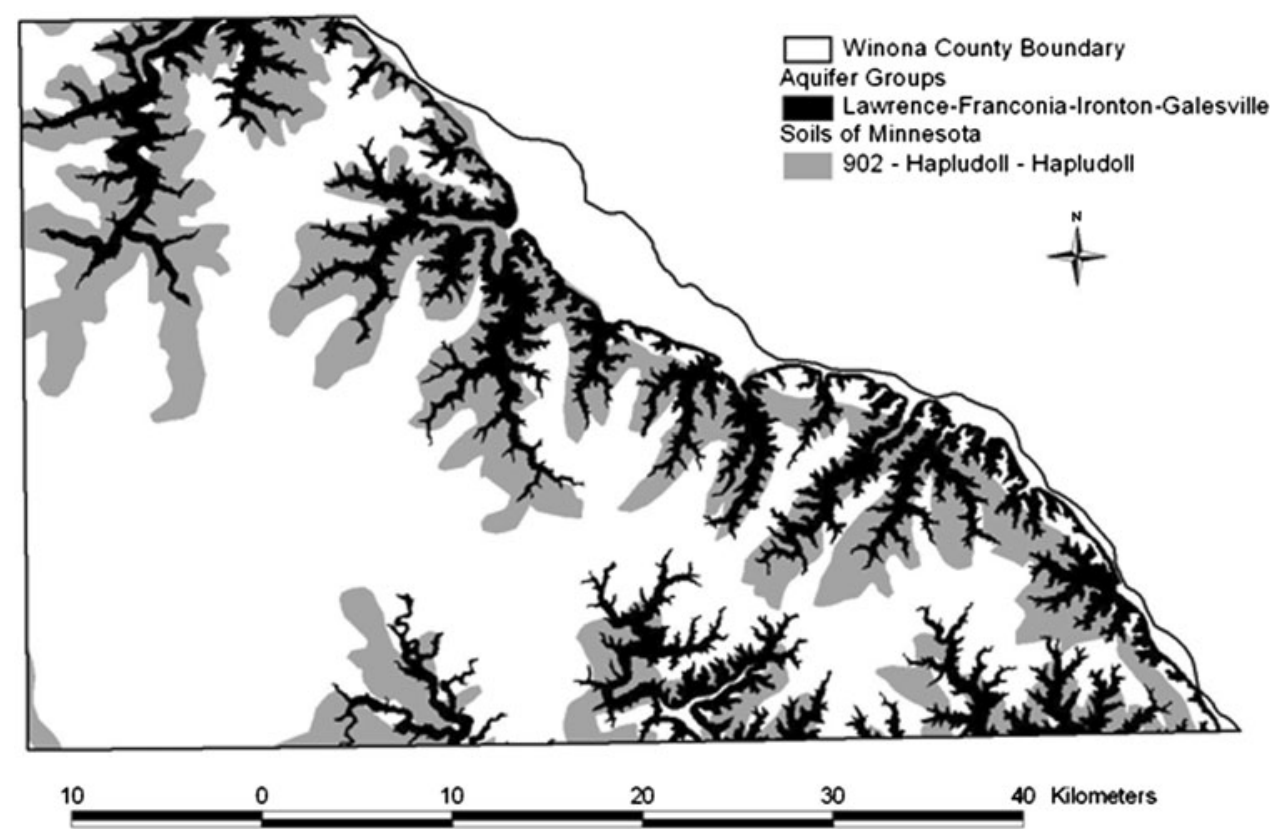

Table 4 Summary statistics for the soil unit associations used in the discriminant function analyses. Soil units 903 and 908 were important variables in both aquifer and bedrock unit analyses. Soil units 419 and 912 were important relative to bedrock units. Soil unit 902 was an important discriminatory variable related to aquifers

\begin{tabular}{|c|c|c|c|c|c|c|}
\hline Soils & $n$ & & Elevation $m$ & $\begin{array}{l}\text { Distance to } \\
\text { nearest bedrock } m\end{array}$ & $\begin{array}{l}\text { Distance to } \\
\text { nearest stream } m\end{array}$ & Slope $(\%)$ \\
\hline \multirow[t]{4}{*}{902} & 153 & Min & 215 & 2 & 0 & 0 \\
\hline & & $\operatorname{Max}$ & 328 & 1,922 & 386 & 66 \\
\hline & & Mean & 259 & 109 & 47 & 25 \\
\hline & & SD & 24 & 184 & 61 & 17 \\
\hline \multirow[t]{4}{*}{903} & 9 & Min & 299 & 29 & 11 & 9 \\
\hline & & $\operatorname{Max}$ & 391 & 772 & 287 & 34 \\
\hline & & Mean & 365 & 363 & 92 & 22 \\
\hline & & SD & 29 & 244 & 104 & 9 \\
\hline \multirow[t]{4}{*}{908} & 14 & Min & 322 & 60 & 9 & 0 \\
\hline & & $\operatorname{Max}$ & 390 & 2,624 & 517 & 25 \\
\hline & & Mean & 367 & 1,215 & 204 & 12 \\
\hline & & SD & 22 & 1,024 & 178 & 9 \\
\hline \multirow[t]{4}{*}{905} & 100 & Min & 231 & 0 & 0 & 0 \\
\hline & & $\operatorname{Max}$ & 358 & 392 & 326 & 63 \\
\hline & & Mean & 293 & 82 & 42 & 26 \\
\hline & & SD & 2 & 66 & 56 & 17 \\
\hline \multirow[t]{4}{*}{912} & 12 & Min & 238 & 1 & 3 & 5 \\
\hline & & Max & 268 & 114 & 226 & 34 \\
\hline & & Mean & 250 & 49 & 73 & 17 \\
\hline & & SD & 9 & 38 & 64 & 10 \\
\hline \multirow[t]{4}{*}{905} & 12 & Min & 202 & 2 & 7 & 3 \\
\hline & & Max & 271 & 279 & 435 & 67 \\
\hline & & Mean & 231 & 92 & 174 & 29 \\
\hline & & SD & 22 & 86 & 172 & 24 \\
\hline
\end{tabular}

Duncan's multiple-range tests identified differences between the bedrock units (Table 2). Elevation was different (Duncan's test, $p<0.001$ ) across all units. Springs in the Prairie du Chien bedrock unit, had the greatest distance to nearest bedrock contact and were significantly different (Duncan's Test, $p<0.001$ ) from the other units. Spring slope was not different among bedrock units. 
Table 5 Initial discriminate function classifications using a random sample of $60 \%$ of the 300 spring observations

\begin{tabular}{|c|c|c|c|c|c|c|c|c|c|c|}
\hline & \multicolumn{5}{|c|}{ Bedrock units } & \multirow[b]{2}{*}{ Total } & \multicolumn{3}{|c|}{ Aquifer units } & \multirow[t]{2}{*}{ Total } \\
\hline & Galena & $\begin{array}{l}\text { Prairie du } \\
\text { Chien }\end{array}$ & Jordan & St. Lawr-Franc & Irntn-Glsville & & Galena & $\begin{array}{l}\text { Prairie du } \\
\text { Chien }\end{array}$ & St. Lawr-Franc & \\
\hline \multirow[t]{2}{*}{ Galena } & 4 & 3 & 0 & 0 & 0 & 7 & 4 & 3 & 0 & 7 \\
\hline & 86 & 14 & 0 & 0 & 0 & 100 & 86 & 14 & 0 & 100 \\
\hline \multirow[t]{2}{*}{ Prairie du Chien } & 1 & 6 & 7 & 1 & 0 & 15 & 1 & 37 & 6 & 44 \\
\hline & 7 & 40 & 47 & 7 & 0 & 100 & 2 & 84 & 14 & 100 \\
\hline \multirow[t]{2}{*}{ Jordan } & 0 & 0 & 24 & 5 & 0 & 29 & & & & \\
\hline & 0 & 0 & 83 & 17 & 0 & 100 & & & & \\
\hline \multirow[t]{2}{*}{ St. Lawr-Franconia } & 0 & 1 & 26 & 88 & 7 & 122 & 0 & 25 & 124 & 149 \\
\hline & 0 & 1 & 21 & 72 & 6 & 100 & 0 & 17 & 83 & 100 \\
\hline \multirow[t]{2}{*}{ Ironton-Galesville } & 0 & 0 & 2 & 9 & 16 & 27 & & & & \\
\hline & 0 & 0 & 7 & 33 & 59 & 100 & & & & \\
\hline \multirow[t]{2}{*}{ Total } & 7 & 8 & 59 & 103 & 23 & 200 & 7 & 63 & 130 & 200 \\
\hline & 3.50 & 4.00 & 29.50 & 51.50 & 11.50 & 100 & 4 & 32 & 65 & 100 \\
\hline \multicolumn{11}{|l|}{ Error count estimates } \\
\hline Rate & 0.14 & 0.60 & 0.17 & 0.28 & 0.41 & 0.32 & 0.14 & 0.16 & 0.17 & 0.16 \\
\hline Priors & 0.20 & 0.20 & 0.20 & 0.20 & 0.20 & 0.20 & 0.33 & 0.33 & 0.33 & 0.33 \\
\hline
\end{tabular}

Diagonal values indicate correctly classified number and percent of springs per geologic layer

Variables that best discriminated spring membership relative to bedrock units were elevation, four soil types, two geomorphology types: TWp2B and Fwi1Rng, forest land cover, trout designation of nearest stream segment and a nearby intermittent stream segment (Table 3). Soil units $419,903,908$, and 912 characterized springs in the bedrock units. Soil unit 419 describes Udorthent or Hapludolldominant groups on steep slopes adjacent to river terraces and floodplains. Soil unit 912 describes fluvaquents, udifluvents, or hapludolls on terraces and floodplains. Springs in these two soil units had the lowest mean slope elevations, shorter mean distances to the nearest bedrock contact and larger mean slopes (Table 4).

The discriminant function analysis discriminated spring membership into bedrock units (Wilks' Lambda $=0.53$, $\left.F_{44,709}=18.7, p<0.001\right)$. Using the reduced set of variables to create a predictive classification matrix of springs classified into bedrock units using a random sample of 200 of the observations, $70 \%$ of observations were correctly classified. Correct classifications were obtained for $86 \%$ of the springs in the Galena bedrock unit, $40 \%$ in the Prairie du Chien, $83 \%$ in the Jordan Sandstones, $72 \%$ in the Franconia Formation and 59\% in the Ironton Galesville (Table 5).

Validating the predictive capabilities of the classification with the remaining 100 observations, $57 \%$ of observations were correctly classified. Correct classifications were obtained for $57 \%$ of the springs in the Galena bedrock unit, $15 \%$ in the Prairie du Chien, $87 \%$ in the Jordan
Sandstones, 59\% in the St. Lawrence-Franconia Formation and 55\% in the Ironton Galesville bedrock unit (Table 6).

\section{Discussion}

Spring distributions

Several characteristics of spring distributions emerged as potentially useful for informing land and water management. Springs were found to be clumped indicating their propensity to be located in central areas within smaller more manageable land areas. The highest number and density of springs were found in the lowest elevations. The highest density of springs and the longest length of trout streams occurred in the St. Lawrence-Franconia Formation bedrock unit indicating the higher occurrence of springs, trout stream segments and subsequently greater management need for this region.

A majority of springs are located on forested land, the only land cover variable important in the aquifer and bedrock unit classifications. Relationships among forest cover, springs and cold-water ecosystems reflect a physical connection having implications for forest, spring and trout stream management (Bowlby and Roff 1986; Sullivan et al. 1987) a connection potentially more sensitive to disturbance in karst regions than would be seen in other geologic land areas (Rivera and Aide 1998). Riparian forest cover that shades discharged spring water, for example, can aid in 
Table 6 Classification of a random sample of $40 \%$ of the 300 spring observations

\begin{tabular}{|c|c|c|c|c|c|c|c|c|c|c|}
\hline & \multicolumn{5}{|c|}{ Bedrock units } & \multirow[b]{2}{*}{ Total } & \multicolumn{3}{|c|}{ Aquifer units } & \multirow[t]{2}{*}{ Total } \\
\hline & Galena & $\begin{array}{l}\text { Prairie du } \\
\text { Chien }\end{array}$ & Jordan & St. Lawr-Franc & Irntn-Glsville & & Galena & $\begin{array}{l}\text { Prairie du } \\
\text { Chien }\end{array}$ & St. Lawr-Franc & \\
\hline \multirow[t]{2}{*}{ Galena } & 4 & 3 & 0 & 0 & 0 & 7 & 4 & 3 & 0 & 7 \\
\hline & 57 & 43 & 0 & 0 & 0 & 100 & 57 & 43 & 0 & 100 \\
\hline \multirow[t]{2}{*}{ Prairie du Chien } & 2 & 2 & 9 & 0 & 0 & 13 & 2 & 24 & 2 & 28 \\
\hline & 15 & 15 & 69 & 0 & 0 & 100 & 7 & 86 & 7 & 100 \\
\hline \multirow[t]{2}{*}{ Jordan } & 0 & 0 & 13 & 2 & 0 & 15 & & & & \\
\hline & 0 & 0 & 87 & 13 & 0 & 100 & & & & \\
\hline \multirow[t]{2}{*}{ St. Lawr- Franconia } & 0 & 0 & 19 & 32 & 3 & 54 & 0 & 21 & 44 & 65 \\
\hline & 0 & 0 & 35 & 59 & 6 & 100 & 0 & 32 & 68 & 100 \\
\hline \multirow[t]{2}{*}{ Ironton- Galesville } & 0 & 0 & 1 & 4 & 6 & 11 & & & & \\
\hline & 0 & 0 & 9 & 36 & 55 & 100 & & & & \\
\hline \multirow[t]{2}{*}{ Total } & 6 & 5 & 42 & 38 & 9 & 100 & 6 & 48 & 46 & 100 \\
\hline & 6.00 & 5.00 & 42.00 & 38.00 & 9.00 & 100 & 6.00 & 48.00 & 46.00 & 100 \\
\hline \multicolumn{11}{|l|}{ Error count estimates } \\
\hline Rate & 0.43 & 0.85 & 0.13 & 0.41 & 0.45 & 0.45 & 0.43 & 0.14 & 0.32 & 0.30 \\
\hline Priors & 0.20 & 0.20 & 0.20 & 0.20 & 0.20 & 0.20 & 0.33 & 0.33 & 0.33 & 0.33 \\
\hline
\end{tabular}

Diagonal values indicate correctly classified number and percent of springs per geologic layer

maintaining low water temperatures in cold-water aquatic ecosystems.

Land-use activities that might reduce forest cover could increase regional land surface temperature (Xiao and Weng 2007), surface runoff, sediment, pollution and warm-water contributions to streams, potentially modifying stream water chemistry (Arthur et al. 1998; Brooks et al. 2003). With potentially increased surface runoff and decreased recharge to springs, cold-water spring contributions to streams could diminish with subsequent degradation to cold-water ecosystems (Sullivan et al. 1987; Blann et al. 2002). Forest best management practices (BMP) that minimize or prevent changes to hydrological characteristics and sediment inputs to springs and stream segments could minimize or eliminate loss of shading for these areas. Vegetated buffers, suggested as a water quality BMP for sinkholes (Peterson and Vondracek 2006), could be used to protect springs and their cold-water contributions to stream ecosystems (Barfield et al. 1998).

After forest lands, springs are predominantly located on parcels designated as a hay/pasture/grassland land cover type. The fact that the bulk of springs are located on these cover types could be due to the methods used in the initial gathering of spring locations reflecting easily identifiable springs chosen on topographic maps (Gao et al. 2002). While these data are spatially accurate, they are not yet complete. With future additions and updates to the karst database, relationships between land cover characteristics and spring management should be further explored.
Spring discrimination into geologic groups

Describing the spatial location of springs, 11 and 8 variables were important for classifying springs into bedrock units and aquifer units, respectively. Seven of these variables were the same indicating overlap in the relationships between geological attributes of aquifers and bedrock units. Several variables were related to the downward fluviokarst weathering process, revealing conduit openings forming the springs in the various geologic groups. Elevation, for example, was significantly different between all bedrock units and all aquifer units, and was an important classification variable for both groups. For the aquifer units, discriminate variables included the soil unit 902 describing Hapludoll-dominant groups on unglaciated or lightly glaciated upland slopes, glacial terranes and floodplains (Cummins and Grigal 1980). The distribution of this soil unit follows the spatial distribution of the lower elevation Franconia-Ironton Galesville aquifer group which had the highest number and density of springs. Also important for classifications was shorter distances to nearest bedrock contact reflecting the close boundaries of the upper Cambrian bedrock strata in the lower valleys.

Classification rates for springs were higher for the three aquifer units than the five bedrock units. This result mainly reflected the larger number of springs for each aquifer unit due to the combining data into fewer aquifer units. However, overlap in values for several variables also affected spring classification and reduced overall classification accuracy. For example, distance to nearest bedrock contact 
was significantly different across several of the bedrock units (Table 3). However, across all springs, the range for this variable was large and overlapping values were found across multiple bedrock units.

Trout stream designation of the nearest stream segment only aided in discrimination of springs in the bedrock units. In low elevations, for over half the springs, the nearest stream segment was a designated trout stream or a protected tributary to a designated trout stream. This association reflects the influence of cold-water springs in maintaining stream temperatures necessary to support viable trout populations in this area (Waters 1977; Anderson 1983), which would be consistent with findings in other regions (Bowlby and Roff 1986; McClendon and Rabeni 1987; Brabrand et al. 2002) and for other coldwater aquatic species (e.g., Alexander and Caissie 2003; Brewer et al. 2007; Whitledge et al. 2006).

In addition to variables describing spring location, other variables may improve discrimination of springs relative to aquifer unit or bedrock unit. Spring aspect, for example, reflecting regional geologic dips (e.g., towards the southwest) and describing the direction of the slope where a spring is located (e.g., southwest) has potential for describing where springs can be located in karst regions (Day et al. 2004). Spring type (e.g., diffuse, conduit, bedrock spring, episodic, intermittent, perennial, etc.) combined with discharge chemistry characteristics could provide additional spring characterization and improve efforts to predict, classify, or characterize springs (Bartodziej and Perry 1990; Bonacci 1993; Alfaro and Wallace 1994). However, neither spring aspect nor spring type is currently documented for the springs in this region.

Conversely, some variables may not be useful for classification purposes. Slope was not significantly different between aquifer units or bedrock units and was not a relevant classification variable. Most springs are located on surfaces with less than a mean slope of $25 \%$. Slope derived from a 30-m DEM, however, may not provide adequate resolution for this region due to the widely distributed tributary valleys, streams and rivers. A DEM with higher resolution, when available, may be more useful for characterizing spring locations.

While this study examined spring characteristics in one county of the southeastern Minnesota karst region, the methods employed could be used for other karst regions with hydrogeologic data available in GIS format. Geologic data are available for most counties in southeastern Minnesota and are organized for use with GIS to convey geologic and hydrogeologic information and interpretation, particularly to local governments (Minnesota Department of Natural Resources 2008b).

There are many benefits of expanding knowledge and management of cold-water systems for human communities in this study region. Studies of the total impact of trout anglers in the four-state Driftless Area estimate regional economic contributions of the annual usage of this natural resource to be in excess of $\$ 1.1$ billion dollars (Gartner et al. 2002; Hart 2008). As a critical habitat component for trout and subsequently an important component supporting the regional trout-fishing industry, quality and quantity of spring discharge could be managed as a regionally important natural resource. Current management of southeastern Minnesota cold-water ecosystems includes in-stream habitat protection and improvement, easement acquisitions, fisheries surveys, stocking, fisheries regulations and agency staff participation in watershed management projects. Regional goals include a statement of recognition of the need to protect and manage sources of cold water for these regional trout streams (Minnesota Department of Natural Resources 2003). However, recent evaluation of county and city policy found no regulatory acknowledgement or protection of springs or spring discharge (Williams 2009) to guide zoning or land-use permits.

Springshed mapping, the mapping of spring recharge areas, is a growing research activity in the southeastern Minnesota karst region (Lopez Burgos et al. 2003; Green et al. 2005; Luhmann et al. 2008) and will provide valuable data concerning the connection between upland recharge areas, spring location, spring discharge characteristics and cold-water aquatic ecosystem health. This additional research in Minnesota and other karst regions will be valuable in pinpointing land areas that have significant impacts on the ecohydrology of a stream system.

\section{Conclusions}

Springs were found to be predominately clumped at low elevations indicating the importance of land management in recharge areas. A subset of variables was shown to be important for classifying springs into two regional geologic groups: bedrock and aquifer units. Classification of springs was most successful relative to aquifer units. However, trout designation of the nearest stream segment aided in discrimination of springs in the bedrock unit indicating a strong relationship between regional bedrock geology and biotic systems. These relationships indicate potential usefulness for the prediction of spring locations for informing land and water management activities such as zoning, easement purchases and development of best management practices in forested land areas.

In karst regions, surface features focus storm-water and melt-water runoff into the subsurface, where little or no filtering of pollutants occur making these hydrologic systems vulnerable to nonpoint source contamination. Thus, 
an understanding of spring characteristics can be especially important in karst regions like that found in southeastern Minnesota. Analyses, such as those provided in this study, could provide land managers with a better understanding of characteristics describing or defining the locations of springs and can add to the growing karst hydrogeologic database. This knowledge can increase accuracy and usefulness of land and water management plans and improve predictability of water and pollutant transport.

Springs are not only a critical hydrogeologic component of streams, lakes and cold-water streams, they also support strong regional social and economic activities. Consideration of upland human activities on spring discharge could lead to informed management activities that protect not only springs, but also their contributions and connections to the viability of regional ecosystems and socioeconomic infrastructure. With future mapping of additional springs and their subsequent entry into the karst spring database, additional research could aid in selecting variables that would improve understanding of springs and their connections with natural and human communities.

Acknowledgments The authors are grateful to the following people for their review of and improvements to this research and manuscript: David Pitt, Department of Landscape Architecture, University of Minnesota; Susy S. Ziegler, Department of Geography, University of Michigan; and Meredith Cornett, Regional Science Director, The Nature Conservancy. Particular thanks are extended to the Regional Environmental Management Division of the Minnesota Pollution Control Agency for their public education workshops in the karst region of southeast Minnesota, helping folks to better understand and more sustainably live in Minnesota's limestone country.

\section{References}

Alexander MD, Caissie D (2003) Variability and comparison of hyporheic water temperatures and seepage fluxes in a small Atlantic salmon stream. Ground Water 41:72-82

Alfaro C, Wallace M (1994) Origin and classification of springs and historical review with current applications. Environ Geol 24:112-124

Amit H, Lyakhovsky V, Katz A, Starinsky A, Burg A (2002) Interpretation of spring recession curves. Ground Water 40:543-551

Anderson DW (1983) Factors affecting brown trout reproduction in southeastern Minnesota streams. Minnesota Department of Natural Resources, Division of Fish and Wildlife, Section of Fisheries Investigational Report No. 376. St Paul, Minnesota

Arthur MA, Coltharp GB, Brown DL (1998) Effects of best management practices on forest streamwater quality in eastern Kentucky. J Am Water Resour Assoc 34:481-495

Barfield BJ, Blevins RL, Fogle AW, Madison CE, Inamdar S, Carey DI, Evangelou VP (1998) Water quality impacts of natural filter strips in karst areas. Trans Am Soc Agric Eng 41:371-381

Bartodziej W, Perry JA (1990) Litter processing in diffuse and conduit springs. Hydrobiologia 206:87-97

Blann K, Nerbonne JF, Vondracek B (2002) Relationship of riparian buffer type to water temperature in the driftless area ecoregion of Minnesota. N Am J Fish Manag 22:441-451
Bonacci O (1993) Karst spring hydrographs as indicators of karst aquifers. J Hydrol Sci 38:51-62

Bowlby J, Roff JC (1986) Trout biomass and habitat relationships in southern Ontario streams. Trans Am Fish Soc 115:503-514

Brabrand A, Koestler AG, Borgstrom R (2002) Lake spawning of brown trout related to groundwater influx. J Fish Biol 60:751-763

Brewer SK, Rabeni CF, Sowa SP, Annis G (2007) Natural landscape and stream segment attributes influencing the distribution and relative abundance of riverine smallmouth bass in Missouri. N Am J Fish Manag 27:326-341

Brooks KN, Folliott PF, Gregersen HM, DeBano LF (2003) Hydrology and the management of watersheds. Iowa State Press, Ames, Iowa

Cummins JF, Grigal DF (1980) Soils and land surfaces of Minnesota. Department of Soil Science, University of Minnesota. St. Paul, Minnesota

Davis RK, Hamilton S, Van Brahana J (2005) Escherichia Coli survival in mantled karst springs and streams, northwest Arkansas Ozarks, USA. J Am Water Resour Assoc 41:1279-1287

Day MJ, Kueny JA, Parrish AK, Tenorio RC (2004) Testing a preliminary model of spring location in the karst of southwestern Wisconsin. Wisc Geogr 20:29-34

Doerfliger N, Jeannin P-Y, Zwahlen F (1999) Water vulnerability assessment in karst environments: a new method of defining protection areas using a multi-attribute approach and GIS tools (EPIK method). Environ Geol 39(2):165-176

Gao Y, Alexander EC, Tipping RG (2002) The development of a karst feature database for southeastern Minnesota. J Cave Karst Stud 64(1):51-57

Gartner WC, Love LL, Erkkila D, Fulton DC (2002) Economic impact and social benefits study of coldwater angling in Minnesota. Final Report for the Minnesota Department of Natural Resources, St. Paul, Minnesota

Green JA, Alexander SC, Alexander EC (2005) Springshed mapping in support of watershed management. Proceedings of the Tenth Multidisciplinary Conference, San Antonio, Texas. 24-28 September 2005, Reston, Virginia

Gvozdetskii NA (1967) Occurrence of karst phenomena on the globe and problems of their typology. Earth Res 7:98-127

Hart AJ (2008) The economic impact of recreational trout angling in the driftless area. NorthStar Economics, Inc. http://www. northstareconomics.com/index.html. Accessed 15 November 2008

Kanivetsky R (1984) Surficial geology, Plate 4. of Balaban. In: Balaban HH, Olsen BM (eds) Geologic atlas of Winona County. Minnesota. Minnesota Geological Survey, St. Paul, Minnesota

Krueger CC, Waters TF (1983) Annual production of macroinvertebrates in three streams of different water quality. Ecology 64:84-850

Lopez Burgos V, Alexander SC, Nagle A, Alexander EC, Green JA, Pavlish J (2003) Recent advances in springshed mapping using dye tracing, GIS and structural geology tools. Paper No. 159-157. Geological Society of America Annual Meeting, Seattle, Washington. http://gsa.confex.com/gsa/2003AM/ finalprogram/abstract_66731.htm. Accessed 1 December 2008

Luhmann A, Alexander SC, Alexander EC, Green JA, Peters AJ, Runkel AC (2008) Combined tools for springshed mapping. Paper No. 253-10. Joint Meeting of The Geological Society of America, Soil Science Society of America, American Society of Agronomy, Crop Science Society of America, Gulf Coast Association of Geological Societies with the Gulf Coast Section of SEPM. http://gsa.confex.com/gsa/2008AM/finalprogram/ abstract 151600.htm. Accessed 1 December 2008

Mahler BJ, Lynch FL (1999) Muddy waters: temporal variation in sediment discharging from a karst spring. J Hydrol 214:165-178 
McClendon DD, Rabeni CF (1987) Physical and biological variables useful for predicting population characteristics of smallmouth bass and rock bass in an Ozark stream. N Am J Fish Manag 7:46-56

Minnesota Department of Natural Resources (2003) Strategic plan for coldwater resources management in southeastern Minnesota 2004-2015. Division of Fisheries. St. Paul, Minnesota

Minnesota Department of Natural Resources (2008a) Arcview resources http://www.dnr.state.mn.us/mis/gis/tools/arcview/ index.html. Accessed 15 May 2009

Minnesota Department of Natural Resources (2008b) County Atlas Regional Assessment Program. http://www.dnr.state.mn. us/waters/groundwater_section/mapping/status.html. Accessed 1 December 2008

Mossler JH, Book PR (1984) Bedrock geology. Geologic atlas of Winona County, Minnesota. County Atlas Series Plate 2 (1:100,000). Minnesota Geological Survey, University of Minnesota

Omernik JM, Gallant AL (1988) Ecoregions of the upper Midwest states. US Environmental Protection Agency. Environmental Research Laboratory, Corvallis, Oregon. EPA/600/3-88-037

Peterson A, Vondracek B (2006) Water quality in relation to vegetative buffers around sinkholes in karst terrain. J Soil Water Conserv 61:380-390

Poff NL, Allan JD (1995) Functional organization of stream fish assemblages in relation to hydrological variability. Ecology 76:606-627

Richards C, Haro RJ, Johnson LB, Host GE (1996) Catchment and reach-scale properties as indicators of macroinvertebrate species traits. Freshw Biol 37:219-230

Rivera LW, Aide TM (1998) Forest recovery in the karst region of Puerto Rico. Forest Ecol Manag 108:63-75

Sullivan K, Lisle T, Dolloff CA, Grant GE, Reid LM (1987) Stream channels: the link between forests and fishes. In: Salo EO, Cundy TW (eds) Streamside management: forestry and fishery interactions. University of Washington, Seattle, Washington, pp 40-97

Tenorio RC, Drezner TD (2006) Native and invasive vegetation of karst springs in Wisconsin's Driftless area. Hydrobiologia 568:499-505
Thorn WC (1988) Brown trout habitat use in southeastern Minnesota and its relationship to habitat improvement. Section of Fisheries Investigational Report No. 395, Division of Fish and Wildlife. Minnesota Department of Natural Resources, St. Paul, Minnesota

Toran L, Herman EK, White WB (2007) Comparison of flowpaths to a well and spring in a karst aquifer. Ground Water 45:281-287

Trimble SW (1993) The distributed sediment budget model and watershed management in the Paleozoic Plateau of the upper midwestern United States. Phys Geogr 14:285-303

Troelstrup NH, Perry JA (1989) Water quality in southeastern Minnesota streams: observations along a gradient of land use and geology. J Minn Acad Sci 55:6-13

USGS-United States Geological Survey (2003) http://geology.usgs. gov/connections/fws/landscapes/karst_map.htm

Vondracek B, Blann KL, Nerbonne B (2000) Habitat-fish relationships across local to watershed scales. In: DuBois R, Kayle K, Ebbers M, Turner S (eds) Trout and the trout angler II. Lacrosse, Wisconsin, pp 7-22

Waters T (1977) The streams and rivers of Minnesota. University of Minnesota Press, Minneapolis, Minnesota

White WB (1988) Geomorphology and hydrology of karst terrains. Oxford University Press, Oxford, UK

Whitledge GW, Rabeni CF, Annis G, Sowa SP (2006) Riparian shading and groundwater enhance growth potential for smallmouth bass in Ozark streams. Ecol Appl 16:1461-1473

Wicks C, Kelley C, Peterson E (2004) Estrogen in a karstic aquifer. Ground Water 42:384-389

Wilcox BP, Owens MK, Knight RW, Lyons RK (2005) Do woody plants affect streamflow on semiarid karst rangelands? Ecol Appl $15: 127-136$

Williams MA (2009) Land cover characteristics in the karst region of southeastern Minnesota. Dissertation, University of Minnesota

Xiao W, Weng Q (2007) The impact of land use and land cover changes on land surface temperature in a karst area of China. J Environ Manag 85:245-257

Zhou W, Beck BF, Pettit AJ, Wang J (2008) Application of water quality control charts to spring monitoring in karst terranes. Environ Geol 53:1311-1321 